\title{
GRAMADO: DA MUDEZ AO CINE POLIGLOTA
}

\section{A produção cinematográfica brasileira teve destaque no Festival de Gramado, principalmente com os curtas-metragens}

Ao mesmo tempo em que, no Continente, três cinematografias celebram seus 100 anos de vida: México, Cuba e Brasil, o Festival de Gramado festejou, em agosto de 1997, seus 25 anos de existência. Para muitos, esses foram anos de resistência devido às dificuldades enfrentadas para se manter esse espaço diante da ausência de produções brasileiras. Em função dessa crise, os organizadores redesenharam as convocatórias e ampliaram seu universo de tal maneira que o Festival se converteu em um certame para o cinema latino com obras realizadas tanto na América Latina quanto na Europa (França, Espanha, Portugal e Itália). Nesta edição de Gramado participaram 16 curtas-metragens, quatro médias-metragens e 15 longas-metragens de ficção entre latinos e brasileiros. Contribuíram para o evento em Gramado as experiências do Festival do Novo Cinema Latino-Americano, que todo ano se realiza em Cuba, na primeira quinzena de dezembro. Este evento consegue aglutinar cineastas e cinematografias de todas as partes do mundo além do novo e pujante movimento de videastas.

Começarei tratando dos curtas e dos médias-metragens, sobretudo dos curtas de ficção. Penso que, dadas as carências finan-

\section{A AUTORA}

\section{Julia Mirabal}

Jornalista cubana, especializada na área de cultura. ceiras, os curtas surgem como resposta às necessidades criativas. Pudemos apreciar roteiros e cenas de filmes que revelam essa busca, demonstram engenho na montagem e incentivam as capacidades potenciais de atuação. Ao mesmo tempo em que revelam novos criadores.

Entre os curtas de ficção que receberam alguns prêmios, embora nem todos os que desejávamos tenham sido premiados, está $O$ Pulso, de José Pedro Goulart.

Interessante reflexão sobre a vida e a morte no sombrio mundo cotidiano de hoje. Trata-se de uma análise psicológica que se valida por seu alcance universal. A realização do filme resulta ágil e original, superando os exercícios cinematográficos apresentados no conjunto. Decisão, de Leila Hipólito, é outro curta de ficção muito apreciado em Gramado. É uma comédia agradável sobretudo para os que viram retratado o brasileiro fanático pelo universo do futebol.

Sem dúvida, o cinema sempre significou a memória gráfica e dinâmica de uma nação, por isso celebro a premiação em Gramado de documentários como o brasileiro Nélson Sargento ou o cubano Eu sou do som à salsa, que são investigações sobre a música popular em ambos os países. Também merece destaque o premiado documentário Recife - de dentro pra fora, um conjunto de imagens formosas e também desagradáveis, mostrando a verdade visual sobre a região. 
Gramado demonstrou uma vez mais a grande capacidade com relação à atuação, garantida por atores de reconhecido talento como é o caso de Nélson Xavier e pelos mais jovens que, às vezes, são descobertos, quase por acaso, nesses eventos, como é o caso de Murilo Benício, jovem ator do curta Decisão e do longa-metragem $O s$ matadores.

Apesar disso, já no terreno dos longasmetragens de ficção, vários aspectos incidem no desnível qualitativo dos filmes. Um deles é a debilidade estrutural dos roteiros, que se relaciona com a pobreza das histórias que contam. As clássicas histórias de amor com as repetidas soluções dramatúrgicas e os esquemáticos pontos de giro, ou seja, variações das linhas de ação. Como por exemplo, no filme $O$ amor está no ar, história de uma profissional já madura que ajuda um jovem marginal e se enamora dele. Essa mesma história contada tantas vezes no cinema, a princesa e o mendigo, nos interessaria se tivesse acentuado o aspecto sociológico deste fenômeno, que vai ocorrer entre as mulheres de mais de 40 anos. Mas parece que os realizadores se confrontaram com algumas dificuldades para terminar a obra e resolveram chegar ao final sem muitos requisitos dramatúrgicos.

Penso, além disso, que o imaginário latino-americano é riquíssimo e ainda inexplorado. Para dizer a verdade, as propostas dos curtas são muito mais atrevidas. Volto ao caso de $O$ pulso, como uma resposta cinematográfica a essa eterna pergunta humana: "depois da morte, o quê?".

Outro dos aspectos que incidem nessa certa desorientação é a influência das coproduções que muitas vezes marcam o rumo e o resultado final dos filmes.
O cinema brasileiro, por causa dos cortes orçamentários do Estado, encontrou algumas soluções para sobreviver. Sempre pretendeu dar receitas, falta agora aproveitá-las bem, convocar jovens roteiristas, quem sabe os mesmos que incursionam nos curtas, afinar a óptica dos caminhos, pontos de vista no exercício da direção.

For all, de Luís Carlos Lacerda e Busa Ferraz, é uma mostra de tentativas cinematográficas, trabalha um pouco com os recursos da televisão e começa a traçar códigos para encontrar novos caminhos ou ao menos retomar alguns extraviados. For all é uma sátira sobre a americanização dos costumes. Alcançou cinco dos kikitos ${ }^{1}$ distribuídos, entre eles o de melhor filme brasileiro.

Questiono os prêmios distribuídos, porque penso que o júri foi muito generoso ao repartir as estatuetas quando o desnível qualitativo era muito evidente e, pelo contrário, filmes como Sob a pele, do peruano Francisco Lombardi, premiado já no Festival Internacional do Novo Cinema Latino Americano, em Havana 96, aqui passou quase despercebido ${ }^{2}$.

Por outro lado, Gramado se enalteceu quando rendeu homenagens ao gaúcho José Lewgoy e ao cineasta cubano Alfredo Guevara, presidente do Instituto Cubano de Arte e Indústria Cinematográfica, pilares do cinema continental nesses últimos 25 anos. Muitos dos presentes agradeceram a Guevara, entre eles Nelson Pereira dos Santos, Orlando Senna, Rui Guerra pelo apoio que sempre foi dado a cineastas brasileiros, sobretudo pelo fato de haver preservado suas obras, escondendo muitas delas em Cuba para evitar que fossem destruídas durante o período da ditadura e repressão.

1. Estatueta oferecida pelo júri do Festival de Gramado aos vencedores das diversas modalidades (filme, direção, roteiro etc.). (N.E.).

2. Na relação de filmes participantes se notou, também, a ausência da produção argentina mais recente que já conta com grande prestígio internacional. 
Para os cineastas da região, Gramado deve permanecer como um espaço a mais para nossas cinematografias. Deve ser um momento para concertação de idéias, para concretizar projetos, para teorizar um pouco sobre os problemas de nossas cinematografias.

Oxalá, nas próximas, essa possibilidade se encontre entre os objetivos do evento.

Resumo: $\mathrm{O}$ artigo trata do Festival de Gramado de 1997. Destaca a filmografia de curtas e médias-metragens, principalmente os curtas O Pulso, de José Pedro Goulart, e Decisão, de Leila Hipólito. Faz crítica à qualidade dramatúrgica dos roteiros dos longasmetragens, que ficaram aquém do ímpeto e da criatividade esperados. Reafirma a importância da realização do Festival como espaço para a filmografia latina, discussão de idéias e projetos que ajudem a superar os problemas desse cinema.

Palavras-chave: Festival de Gramado, curtametragem, cinema latino, longa-metragem
Gramado foi capital do cinema, por uns dias de agosto, e sua população lhe agradeceu muito. As personalidades convidadas também. Portanto, que exista esse Festival, que se mantenha e que conte com o apoio de toda a gente que ama o cinema em nossos países, porque, como afirmava um brasileiro na noite final, "o cinema, quando deixou de ser mudo, o fez para falar em vários idiomas e não somente em inglês".

Abstract: The article deals with the 1997 Gramado Festival. It highlights the filmography of short and mid-sized motion-pictures, most especially the José Pedro Goulart's short motion-picture $O$ Pulso (The Pulse), and Leila Hipólito's Decisão (Decision). It criticizes the dramaturgical quality of the major motion-picture scripts, which are far from having the impetus and creativity one may expect from them. It stresses the importance of the Festival's being carried out as a space for the Latin filmography, idea discussion, and projects, which help to overcome the problems this genre has.

Keywords: Gramado Festival, short motionpictures, Latin cinema, long motion-pictures 